\title{
Study on the Connotative Development of Chinese Higher Vocational Education
}

\author{
Haisha Su \\ Kunming Metallurgy College \\ Kunming, China
}

\begin{abstract}
The Chinese higher vocational education has experienced forty-year development, gone through the stages of initial exploration and scale expansion and entered the stages of connotative development and quality promotion. The orientation of talent cultivation has been changed into skill culture from the skills and this will be the source power for the sustainable development of higher vocational education.
\end{abstract}

Keywords-higher vocational education; connotative development; skill culture

\section{INTRODUCTION}

Since 1978, the Chinese modern higher vocational education has gone through the forty-year course. With the changes in forty years, there have been great changes from theory on school management to model of teaching and the connotative development model has tended to be mature.

\section{REVIEW ON THE DEVELOPMENT COURSE OF HIGHER VOCATIONAL EDUCATION}

The modern higher vocational education began since the resumption of university entrance examination. In 1977, the resumption of university entrance examination system of China enables the specialist education to be continued. However, the specialist education at that time all belongs to compression-type undergraduate course but not the vocational education in the strict sense on the perspectives of teaching and talent cultivation. In 1978, a few of regions begin to conduct a trial run of management of local vocational colleges which possess the natures of higher vocational education and represent the starting of higher vocational education of China.

In 1985, the first national education working conference was held. After that, it was firstly pointed out in the issued Decision of Central Committee of the Communist Party of China on Educational System Reform that "the vocational technical education is exactly the weakest link in the entire current education business of China"; "we need to actively develop the higher vocational and technical colleges" and "gradually establish the vocational and technical system covering from junior to senior with industrial matching, reasonable structure and mutual communication with common education". In the same year, the State Education Commission of the PRC launched the pilot project of five-year postsecondary education. From now on, the higher vocational education entered the stage of exploration and adjustment.
In 1994, the second national education working conference was held which has the milestone meaning on higher vocational education. This conference took development of higher vocational education as the focus of higher education development and clearly put forward the "three-system reform and one-supplement" which is "to reform the school-running models and adjust the cultivation goals to develop higher vocational education through the existing vocational colleges, part of the higher technical colleges or independently set-up adult colleges and use a few of qualified key secondary specialized schools to conduct system reform or hold the vocational courses as supplement to develop higher vocational education upon approval when the above cannot meet requirements". Then, the Ministry of Education put forward that to develop higher vocational education, the key is educational reform and it will require the higher vocational colleges to manage the higher vocational education with characteristics.

In 1999, the third national education working conference issued the decision of Central Committee of the Communist Party of China and State Council on Deepening the Educational Reform and Comprehensive Promotion of Quality-Oriented Education which pointed out that "to strive to develop higher vocational education, we need to cultivate a large batch of special talents with necessary theoretical knowledge and relatively stronger practical ability that are badly in need of front lines including production, construction, management and service, etc as well as countries" and made the initial statement on the talent cultivation in higher vocational education. In 2000, the Opinions on Reinforcement of Talent Cultivation Works for Higher Vocational and Higher Technical Education issued by Ministry of Education defined the objective of talent cultivation for higher vocational and higher technical education as "application-oriented special talents that can adapt to first lines including production, construction, management and service" and firstly put forward the principle of "indispensable theory teaching and enough as limit". In 2004, the Several Opinions on Employment Orientation and Deepening Reform on Higher Vocational Education issued by Ministry of Education put forward the development road of higher vocational education; the purpose of service, the orientation of employment and the development road with combination involving production, teaching and research. In a few years, with the increased enrollment of higher education, the school-running scale of higher vocational colleges is also rapidly expanded. And our understanding on 
higher vocational education is also continuously deepened and we will have clear understanding on the cultivation of higher vocational education talents. It also stressed the skill requirements on front line posts of higher vocational education, stressed the technical application of talents and stressed the occupational requirements. The employment orientation of education should be very clear.

So far, from the perspective of concept, the higher vocational education is transformed from undergraduate course compression-type into vocational education-type. And we realize the significant meanings of application and technical nature on higher vocational education. A batch of higher vocational colleges has made specific researches $o$ the technical skill education on the cultivation of talents which highlights the natures of vocational education. This is the important achievement on the educational theories in the over20-year higher vocational education development since resumption of university entrance examination. However, during the actual school-running process, there are still no obvious breakthroughs on the talent cultivation models in higher vocational colleges and such models have not been truly acknowledged by the society.

In 2006, the Ministry of Education issued the Several Opinions on Comprehensive Promotion of Teaching Quality of Higher Vocational Education which was the important guidance document for the connotative development of higher vocational education. The document defined that the higher vocational education is one of higher education types and possesses corresponding education system. The document removed the "research" from the "development road with combination involving production, teaching and research" and positioned the talents cultivation for higher vocational education as "cultivation of thousands of high-quality skillbased talents for the socialist modernization construction", which distinguished the talents cultivation for higher vocational colleges from that for common colleges. It is pointed out in the document that the higher vocational colleges should put the work emphasis on the improvement of quality, which is to put forward definite requirements on the connotative development of higher vocational education. The document stressed that:" the higher vocational colleges should insist on the principles including people first and moral education first and should integrate the socialist core value system into the whole process of talents cultivation for higher vocational education"; "pay high attention to the professional ethics education and legal education for students, pay attention to cultivation of quality of integrity, professional dedication and sense of duty, awareness of observing law and discipline of students and cultivate a batch of high-quality skill-based talents"; "educate students to learn communication and teamwork, improve the practical ability, creative ability, employability and entrepreneurial ability of students"; the requirements on talents cultivation for higher vocational education has been promoted to the level of comprehensive quality from pure skill.

In the same year, the Ministry of Education proposed to implement the plans of demonstrative higher vocational college construction and construct 100 demonstrative higher vocational colleges nationwide so as to promote the connotative development of higher vocational education. The promotion of construction of one hundred demonstrative higher vocational colleges on the higher vocational education of China is outstanding and it has practically brought the demonstration effects to the over 1400 higher vocational colleges.

In May 2014, the Decision of State Council on Speeding Up the Modern Vocational Education proposed to speed up construction of modern vocational education system, adopt the measures including trial run promotion and demonstration orientation, conduct undergraduate vocational education and perfect the enrollment measure of "cultural quality + vocational skills", etc at the same time. In 2015, the Action Plans (2015-2018) for Creative Development of Higher Vocational Education issued by Ministry of Education required: "the initial formation integrated with humanistic quality, professional spirit and vocational skills" and "enhancement of ideological and political education works for students of higher vocational education with the characteristic of cultivation of professional ethics and professional qualities, focusing on cultivation of skill-based talents who can not only master proficient skills but also can stick to the professional spirits" and "promotion of integration of cultivation of vocational skills and professional spirits". In the same year, after putting forward the Action Plans (2015-2018) for Promotion of Vocational College Management Level, it was proposed that the higher vocational colleges should develop the construction of high-level schools and high-level majors which is also the powerful measure for higher vocational colleges to further intensify the connotative development.

From the perspective of requirements of Ministry of Education on higher vocational education development, we have always been exploring on the road of higher vocational education with Chinese characteristics. Both the policy level and practical level all define that the higher vocational education should be changed from external development to the connotative development.

\section{THINKING ON THE CONNOTATIVE DEVELOPMENT OF HiGHER VOCATIONAL EDUCATION}

\section{A. Connotative Development Is the Inevitable Requirement of Higher Vocational Education Development of China}

As a clear concept, the symbol of higher vocation education is that the Vocational Education Law of China issued in 1996 and the Higher Education Law issued in 1998 have successively specified the scope of application of laws for "higher vocational college education".

The Chinese higher vocational education possesses distinct Chinese characteristics and original characteristics. Since 1978, from initial starting to the exploration and adjustment to creative promotion stage and from scale expansion to stable scale, the Chinese higher vocational education has already been changed from external development requirements to the connotative development requirements.

With the coming of new era, the principal contradiction of higher education of China is also correspondingly reflected in the contradictions between requirements of people on the 
quality of higher education and the unbalanced and insufficient development of higher education. One of the manifestations of this contradiction is the unbalanced development of common higher education and higher vocational education. In general, the school size of higher vocational education is basically the same with that of common higher education, however there are clear difference on the quality of talent cultivation which is mainly manifested on the connotative construction and the distinct characteristics of talents. The second contradiction manifestation is is the contradiction between cultivation objective and demand of social development on higher vocational education and the insufficient higher vocational education development. With the adjustment and upgrading of industrial structure of China, the demands of talents for vocational education have become increasingly apparent. In 2015, the State Council issued the Made in China 2025 which was the program of action for implementation of strategy of manufacturing power. As the support and guarantee for the development of manufacturing industry of China, the higher vocational education must take the sustainable development path. As the main responsible unit of higher vocational education, to cultivate the talents who possess the abilities to promote industrial reform and speed up the transformation of economic development modes, the higher vocational colleges must take the connotative development path and should manifest the cultural characteristics of higher education. And the higher vocational education culture should possess both the advance and professionalism and should take professionalism as characteristic.

\section{B. The Core of Connotative Development of Higher Vocational Education Manifests Skill Culture Characteristic}

From the perspective of policy requirements, the Ministry of Education has clearly put forward requirements on the connotative development of higher vocational education and adopted corresponding measures, such as construction of national demonstrative higher vocational colleges, construction of high-quality colleges, construction of high level colleges and construction of high level majors, etc. And many higher vocational colleges also realize the necessity and importance of connotative development. Some of the excellent higher vocational colleges also put forth efforts to explore and practice and have obtained significant achievements. If the higher vocational colleges want essential development, they need to enhance the strength of culture characteristic construction, integrate the skill culture into major construction and into the daily course teaching which is the core meaning of connotative development.

With the research of personage in the field of higher vocational education on the connotative construction of higher vocational education, the skill culture is also gradually receiving attention from the field of higher vocational education and the researches thereon are also arising.

In July 2013, the Chinese candidate participated in the 42nd World Skills Competition. This is the second time of China to participate in the World Skills Competition. The competitions with the candidates from various countries in the world make the candidates obtain plenty of thinking and enlightenment, find the difference and deficiency. They rethink the skilled talents cultivation modes of China and think that we need to enhance the cultivation of comprehensive vocational ability of students in addition to the proficiency of skills mastered. They have experienced the deep skill culture deposits". The most far-reaching influence of this competition on candidates is the awareness of skill culture and they make the appeal that "the construction of skill culture is just in time". This is the first time for "skill culture" to appear in the form of a complete phrase.

In 2016, Wang $\mathrm{Zi}$, the Principle of Kunming Metallurgy College made the more comprehensive and deeper understanding on the cultivation of skill culture of higher vocational colleges in the text of "Exploration and Practice of Skill Culture Cultivation of Higher Vocational Colleges. Wang $\mathrm{Zi}$ conducted conceptual description from the operation level, system level, behavior level and spirit level and discussed the practical level of skill culture cultivation from the five aspects including major setup, teaching resource configuration, schoolenterprise cooperation, organization forms of skill competition and cultivation carriers, etc. He thinks that the skill culture can evenly coordinate the "advance" with "professionalism" of higher vocational education so as to finally achieve the final objective of education and promote the development of "human".

The skill culture is the important characteristic of cultural construction of higher vocational college which is different from that of common colleges. The research on skill culture is the new concept proposed in the development of higher vocational education of China setting out from the social demands of talent cultivation to define the educational theory and school-running position. Currently, the research of people on skill culture mostly remains in the understanding on importance but rarely involve its connotation and cultivation approach. However, the proposing of skill culture shows that we have made bigger advancement on the connotative development of higher vocational education and that the orientation of connotative construction is more specific and the cognition is more profound.

\section{Connotation OF SkILl CUlture}

Skills are human centered. The only carrier of skills is an individual with abilities, skills and talents. Culture refers to the "culture ruling and education" of people, which is a kind of edification and a natural quality that radiates naturally from the inside out. And people's attitude, perceptions and understanding towards skills, and the expression of skills and values of skilled people can be called skill culture. Many phenomena show that skilled people do not necessarily have the skill culture. The pursuit of skill culture education is not to enable students to master only "skills". Instead, students need to experience and understand the meaning of life in learning and mastering skills, so as to determine your values, world outlook and outlook on life. A person with skills and culture is a professional, lifestyle oriented ways of act, thinking modes and value concept.

Skill culture is the core and key of higher vocational education in essence. After World War II, the economics in 
Germany and Japan was greatly improved, which were inseparable from their understanding and importance of vocational education and their cultivation of skills and culture. The "craftsmanship spirit" that we often talk about is the embodiment of skill culture.

We believe that higher vocational colleges' skills culture mainly includes four aspects: technical skills, professional spirit, professional thinking and career development ability.

Technical skill is the basic content of skill culture, which generally refers to the degree of understanding and proficiency in a job, especially for specific activities involving methods, processes, procedures, or techniques.

Professional spirit is sublimated on the basis of professional ethics. Different professions with different professionalism, but they all clearly express the fundamental interests of the profession, and the spiritual requirements of professional responsibilities and professional behavior. The top technical skills can only be reflected in good professional spirit. Otherwise, it will even go to the extreme of endangering the society. Professional spirit is the mission of skill culture education.

There is a lot of research on professional spirit. In brief, the professional spirit of any occupation includes career ideal, professional attitude, professional responsibility, professional discipline and professional style. Professional ideals are professional values and the soul of professional spirit. When choosing a career, people want to combine personal strengths and personal interests with service society, personal career ideals with social interests. Professional attitude is the precondition of doing a good job. A person with a correct career ideal will have a good professional attitude. The work enthusiasm and the performance of duties, or even the quality of the products, all depend on people's professional values. Professional responsibility is an important part of professional spirit, including two aspects: group responsibility and individual responsibility. The key to cultivating professional responsibility is to transform the professional responsibilities of external requirements into the behavior choices of internal consciousness. Professional discipline has a mandatory feature, but its most prominent feature is its support from inner beliefs, reflecting the internal binding force and the conscious obedience. This is the unity of law and morality. Professional style is a habitual expression of practitioners in their professional life. Individual professional style is easy to be influenced by the collective professional style.

Professional thinking is the viewing angle of people thinking and choosing behavior. In brief, it is a kind of thinking or habit that professionals need to have in their daily work. But work is not limited to this conventional thinking. For example, legal professionals are accustomed to analyzing problems with procedural and legal analysis, while the ones engaged in economic industry are accustomed to measuring the rationality of a decision by using economic benefits. In view of the same problem, jurists will analyze it from legality, how the law stipulates, and how the process flow can be analyzed, while economists will consider it in terms of cost and return on investment, capital and tax risk. People with good professional thinking have the corresponding "habitual" thinking about how to effectively complete the work, how to control the work process, and how to integrate the working environment. This kind of professional thinking is accumulated and perfected in daily learning practice. And these thoughts not only affect their professional performance, but also affect their daily life cognition and behavior.

Career development ability refers to the potential of practitioners to adapt to technological and social development and change in their professional abilities after obtaining basic vocational and technical skills. With the development of modern science and technology and the change of market demand, through the necessary learning and practice, we can quickly and effectively enhance our professional value. It is a capacity for sustainable development. The students with professional development ability are forward-looking to the development of vocational value chain and change of their profession, and make the initiative to lay the foundation for expanding their own career development.

\section{Skill Culture Cultivation Practice}

In recent years, the cultural construction of higher vocational colleges has achieved remarkable results, but there is still a great distance from the development requirements. In the practice of cultivating skill culture, there are some problems that cannot be ignored in the subjective and objective aspects.

Subjectively, higher vocational colleges do not raise skill education to the level of skill culture education. They consider vocational education as vocational skills training, and make it simple to serve employment. In fact, such employment service is, in essence, just a short-term employment service, lacking the competitiveness of long-term development and the support of career planning and development. It has a gap from the goal of higher vocational education and our talent cultivation goal. And the cultivation of skills culture lies in improving students' comprehensive quality and sustainable development ability. Skill is only the foundation, culture is the source of power, and skill culture is the core competitiveness.

Since 2000, objectively the scale of higher vocational colleges has expanded, so that the number of students in each school has doubled or even increased by ten times. However, the number of teachers and teaching resources has been increased slowly, and many schools have a large gap in school funding. This has also made obvious constraints on the cultural construction and connotation development. And the teaching structure is transformed from the past theoretical teaching as main to the theoretical and practical teaching, which puts forward higher requirements for the teaching staff. The development of "dual-teacher" teaching staff is the development resistance for most of higher vocational colleges, which challenges the development of higher vocational education. The development of teaching staff is an important driving force for the connotation development of higher vocational colleges.

The most important way to cultivate the skill culture is to integrate the skill culture into the professional construction and the curriculum system, not just on the campus culture level. We cannot talk about skills culture out of professional 
construction and curriculum system. As a teacher, in daily teaching activities, we shall combine professional knowledge with professional thinking, professional quality, professional ethics and comprehensive quality. For example, the workflow and security operation shall be interpreted from the working principle. The professional quality can be improved gradually from the use of equipment to maintenance, from drawing to preservation, and the habit formation of other daily work details. Secondly, school enterprise cooperation is an accelerator for skills culture cultivation. Through the schoolenterprise cooperation project, it is conducive to put the enterprise's requirements for talents, the production process standardization of enterprises, and the integration of enterprise culture into the education and training of schools. Thirdly, through combining the classroom teaching with the extracurricular practice, the school learning with the enterprise learning and the skill practice with the cultural quality, skill culture can be truly cultivated.

\section{CONCLUSION}

Skill culture is the category of culture. Like all cultures, it is a long historical precipitation process from skill to skill culture. It is the characteristic connotation of the development of higher vocational education and the source for sustainable development of higher vocational education.

\section{REFERENCES}

[1] Jiang Dayuan Study on Unique Contribution of China's Higher Vocational Education to world education [J] Chinese Vocational and Technical Education, Issue 36 of 2015. 姜大源 论中国高等职业教育 对世界教育的独特贡献 [J] 中国职业技术教育 2015 年第 36 期.

[2] Zhou Jiansong Research on Cultural Construction of Higher Vocational Colleges based on Connotation Development [J] Journal of Tianjin Vocational Institute Issue 4 of 2016. 周建松基于内涵发展的高职院校 文化建设研究 [J]天津职业大学学报 2016 第 4 期.

[3] Wang Zi Cultivation of Technical Culture in Higher Vocational Colleges [J] Vocational \& Technical Education Forum Issue 8 of 2016. 王资 高职院校技能文化的培育 $[\mathrm{J}]$ 职教论坛 2016 年第 8 期.

[4] Zhou Jiansong Research on Connotation Development of Higher Vocational Education based on Cultural Perspective Issue 8 of 2013. 周 建松 基于文化视域的高职教育内涵发展研究[J]中国高教研究 2013 年第 8 期.

[5] Sun Yan Recessive Characters of Higher Vocational Education [J] China Adult Education Issue 9 of 2010. 孙琰 高等职业教育的隐性特 征 [J]中国成人教育 2010 年第 9 期.

[6] Wang Yiqiu General Education Mission and Its Teaching Diversification [J] China University Teaching Issue 10 of 2016. 王义遒 通识教育使命及其教学多样化[J]中国大学教学 2016 年第 10 期.

[7] Jiang Dayuan Vocational Education: Debate on Technology and Skill [J] Chinese Vocational and Technical Education, 2008 (34). 姜大源 职业 教育: 技术与技能辩 [J] 中国职业技术教育, 2008（34）.

[8] Luo Xiao Right Season of Creating a Skill Culture [J] Occupation Issue 26 of 2013. 骆潇 打造技能文化正当时 [J] 职业 2013 年第 26 期. 